\title{
Estimation of the Heritability for Growth Traits at 3 Months and 5 Months of Pacific White Shrimp, Litopenaeus Vannamei
}

\author{
Ru-Wei XU1 ${ }^{1}$, Pham Xuan $\mathrm{CHINH}^{2}$, Rasha Mahmoud FAISAL ${ }^{2}$, \\ Xiao-Lin LIU ${ }^{2}$, a, * \\ ${ }^{1}$ College of Marine Sciences, Ningbo University, Ningbo 315211, China \\ ${ }^{2}$ College of Animal Science and Technology, Northwest A\&F University, Yangling \\ 712100, China \\ aemail: liuxiaolin@nwsuaf.edu.cn. \\ *Corresponding author: Tel.: +86 29 87092102, Fax: +86 2987092164.
}

Keywords: Litopenaeus vannamei, Growth, Heritability, Genetic parameters, Half-sib family.

\begin{abstract}
To provide the necessary genetic parameters for Litopenaeus vannamei breeding program, the heritabilities were estimated in the breeding process. Heritabilities were estimated for the body weight (BW), total length (TL), the body length (BL), first abdominal segment depth (FASD), third abdominal segment depth (TASD), first abdominal segment width (FASW), partial carapace length (PCL) of L. vannamei were measured in 3-5 months old. The estimates were calculated from 7 body measurements on progeny resulting from a nested mating design. 17 half-sib families and 42 full-sib families of $\mathrm{L}$. vannamei were obtained by artificial assistant fertilization of 2-5 females with a single male, and the measurements were obtained 3-5 months after metamorphism. Point estimate for heritabilities based on the sire component were moderate, and they were $0.452 \pm 0.029,0.368 \pm 0.025,0.387 \pm 0.026,0.403 \pm 0.023$, $0.415 \pm 0.033,0.441 \pm 0.028,0.422 \pm 0.027$ for BW, TL, BL, FASD, TASD, FASW and PCL at 3 month, and $0.515 \pm 0.031,0.394 \pm 0.028,0.409 \pm 0.028,0.412 \pm 0.028$, $0.420 \pm 0.029,0.429 \pm 0.029,0.415 \pm 0.028$ for BW, TL, BL, FASD, TASD, FASW and $\mathrm{PCL}$ at 5 month, respectively, all of which differ significantly from zero $(\mathrm{P}<0.01)$.
\end{abstract}

\section{Introduction}

Genetic improvement of breeding stocks becomes increasingly important in aquaculture, even slight improvement, body weight and size magnitude would result in surprised advance when the heritability is high. In breeding programs, body size is a common performance trait at a certain age. Heritability and genetic correlation are two important parameters that measure the relative magnitude of additive genetic variation and co-variation. Henderson's (1973) pioneering work provided a technique that enabled the separation of genetic and environmental effects when predicting bull and cow breeding values. The technique has now dominated the analysis of data from livestock improvement schemes, both in the prediction of breeding values and the estimation of genetic parameters. Most early published estimates of genetic parameters in aquatic animal breeding have been calculated by methods of least squares or by regression of response on selection differentials (Hetzel et al, 2000; Gjedrem and Olesen, 2005; Neira et al, 2006; Maluwa and Gjerde, 2007; Rezk et al, 2009). Recently, aquatic animal breeding literature shows that the nested analysis of variance model are beginning to be used to estimate variance components in some species (Andriantahina et al, 2011; Ibarra et al, 2005; Nhan et al, 2009). 
The estimates of heritabilities and genetic correlations for many aquatic species have been reported. The heritabilities and genetic correlations estimated from full-sib analysis of female progeny of crosses from three domestic rainbow trout stocks were moderately high $(0.32-0.52)$ for each of post-spawning body weight, egg number, egg size, egg volume (Gall and Gross, 1978; Huang and Gall, 1990; Gall and Bakar, 1999). In addition, they reported that there were favorable and moderate to high genetic correlations between spawning body weight, egg volume, egg number and egg size. Norris and Cunningham (2004) reported that heritabilities of the body weight and flesh color of the Atlantic salmon were $0.6 \pm 0.3$ and $0.2 \pm 0.1$ and the genetic correlation was $0.4 \pm 0.5$. Fishback et al (2002) reported that heritabilities of total length, weight and condition factor of rainbow trout ranged from 0.36 to 0.719 , and the genetic correlation was $0.60 \pm 0.049$. Ibarra et al (1999) reported that the realized heritability of total weight was higher $(0.33 \pm 0.08$ to $0.59 \pm 0.13)$ than that of shell width $(0.10 \pm 0.07$ to $0.18 \pm 0.08)$ in catarina scallop, Argopecten ventricosus; estimates of the genetic correlation between the two traits varied widely between experiments $(1.25 \pm-0.22$ in experiment 1 and $0.33 \pm 0.31$ in experiment 2). Jonasson et al (1999) reported that the heritability of 4-month cultured red abalone (Haliotis rufescens) in iceland was estimated to 0.11 ( 0.33 on the liability scale) and for shell length at the age of $8,10,18$, and 24 months to $0.08,0.06,0.27$, and 0.34 , respectively. In coho salmon, the heritability of number of green (total) eggs was $0.42 \pm 0.08$ and eyed (fertile) eggs $0.33 \pm 0.08$ (Gall and Neira, 2004). Jonasson (1993) reported that the estimated heritabilities of broodstock of Atlantic salmon (Salmo salar) calculated based on sire components from the total material were 0.04 for survival, 0.16 for weight, and 0.10 for length when weight and length were adjusted to egg size and number of fish per tank. The heritability estimated for weight ranged from 0.380 to 0.600 in Oreochromis niloticus (Charo-Karisa et al, 2006) and from 0.120 to 0.560 reared in seven different test environments (Eknath et al, 2007). Toro (1990) reported that heritability for live weight and shell height in the European oyster Ostrea edulis ranged from 0.112 to 0.243 and the genetic correlations between the traits were found to be high at 0.963 and 0.995 for the first and second growing season, respectively. Hilbish (1993) reported that narrow sense heritability estimated for shell length was $0.58 \pm 0.10$ for prodissoconch and $1.08 \pm 0.29$ for 2 -day old larvae and there was significant and positive genetic covariance between these two traits in Mercenaria mercenaria. Coman et al (2010) found moderate genetic correlation between shrimp weight at week 24 and week $32(0.62 \pm 0.19)$. The moderate heritabilities for weight between week 24 and week 32 (0.23 to 0.39) were lower than that reported previously in P. monodon (Kenway et al, 2006; Macbeth et al, 2007) and L. vannamei (Argue et al, 2002); but consistent with values reported in several studies for other shrimp species (for instance, Hetzel et al, 2000; Perez-Rostro and Ibarra, 2003; Gitterle et al, 2005). To date, there have been rather limited literatures providing estimates of genetic parameters for the reproduction traits of penaeus species (Arcos et al, 2004, 2005; Ibarra et al, 2005). Perhaps other highly fecund aquaculture species follow the same evolutionary strategy with similar selection dynamics and heritabilities. $\mathrm{Su}$ et al (1997) reported that the estimated values of heritability were 0.65 for spawning date, 0.14 for spawning body weight, 0.60 for egg size, 0.55 for egg number, 0.52 for egg volume and 0.13 for fertility-hatchability. Spawning date had significant genetic correlations with spawning body weight, egg size and egg volume (0.51-0.73) as well as with egg number (0.25). Significant genetic correlations were also found for spawning body weight with egg size, egg number and egg volume (0.47-0.67), and for egg size with fertility-hatchability (0.35). Argue et al (2002) reported that the half-sib heritability estimated for growth was $0.84 \pm 0.43$; the realized heritability for TSV 
resistance was $0.28 \pm 0.13$. Benzie et al (1997) reported that the estimates for the heritability in size of juvenile P. monodon from half-sib mating were approximately 0.10 for both length and wet weight at 6 and 10 weeks. Nguyen Hong et al (2014)reported heritability for body colour and its genetic association with morphometric traits in Banana shrimp, and Kenway et al(2006) reported heritability and genetic correlations of growth and survival in black tiger prawn Penaeus monodon reared in tanks. Whatmore et al (2013) reported henetic parameters for economically important traits in yellowtail kingfish Seriola lalandi. Hung et al (2013) reported Quantitative genetic parameter estimates for body and carcass traits in a cultured stock of giant freshwater prawn.

\section{Materials and Methods}

\section{Experimental Design}

A classic nested mating design developed by Comstock and Robinson (1952) was employed to partition the phenotypic variation into its genetic and non-genetic causes. In this experiment each of 17 male L. vannamei was mated to an average of 3-5 females, thus generating 42 full-sib families and 17 half-sib families. Variance components for each trait were estimated using a single-trait animal model, while covariance components for pairs of traits were estimated using a two-trait animal model. The effects of males and females nested within males on growth were separated using nested analysis of variance (ANOVA).

\section{Genetic Analysis}

The covariance among full- and half-sibs provides the basis for the decomposition of phenotypic variance into genetic and environmental components of variance. The covariance among full- and half-sibs were calculated from the observed components of variance obtained from a three-level nested, ANOVA (Table 1) and the General Linear Models procedure of the Statistical Analysis System (SAS) (Kovac and Groeneveld, 2003).

The experiment was a three-level classic nested, unbalanced design. Therefore the number of offspring in dams and in sires and in dams within sires should revise. The Effective Means were computed using the equations:

Effective mean number of offspring in dams within sires: $\mathrm{K}_{1}=\left[\mathrm{N}-\Sigma\left(\mathrm{n}_{\mathrm{ij}}{ }^{2} / \mathrm{dn} \mathrm{n}_{\mathrm{i}}\right)\right] /(\mathrm{D}-\mathrm{S})$

Effective mean number of offspring in dams: $\mathrm{K}_{2}=\left[\Sigma\left(\mathrm{n}_{\mathrm{ij}}^{2} / \mathrm{dn}_{\mathrm{i}}\right)-\Sigma\left(\mathrm{n}_{\mathrm{ij}}^{2} / \mathrm{N}\right)\right] /(\mathrm{S}-1)$

Effective mean number of offspring in sires: $K_{3}=\left(N-\Sigma n_{i} / N\right) /(S-1)$ in which $\mathrm{S}=$ number of sires, $\mathrm{D}=$ number of dams, $\mathrm{n}_{\mathrm{ij}}=$ number of offspring of the $\mathrm{i}$-th sire and $\mathrm{j}$-th dam, $\mathrm{dn}_{1}=$ number of offspring of $\mathrm{i}$-th sire, $\mathrm{N}=$ sum of number of offspring of all sires .

The variance and covariance of characters among different groups were calculated in Table 1. 
Table 1. Analysis of variance and covariance for components of phenotypic variation

\begin{tabular}{ccccc}
\hline $\begin{array}{c}\text { Source of } \\
\text { variance }\end{array}$ & $\begin{array}{c}\text { Degree of freedom } \\
(\mathrm{df})\end{array}$ & $\begin{array}{c}\text { Sum of squares } \\
(\mathrm{SS})\end{array}$ & $\begin{array}{c}\text { Mean square } \\
(\mathrm{MS})\end{array}$ & $\begin{array}{c}\text { Expected mean square } \\
\mathrm{E}(\mathrm{MS})\end{array}$ \\
\hline Dams & $\mathrm{S} \times \mathrm{D}-1$ & $\mathrm{SS}_{\mathrm{D}}$ & $\mathrm{MS}_{\mathrm{D}}$ & \\
Sires & $\mathrm{S}-1$ & $\mathrm{SS}_{\mathrm{S}}$ & $\mathrm{MS}_{\mathrm{S}}$ & $\sigma^{2}+\mathrm{k}_{2} \sigma_{\mathrm{D}}{ }^{2}+\mathrm{k}_{3} \sigma_{\mathrm{S}}^{2}$ \\
Dams/sires & $\mathrm{S} \times(\mathrm{D}-1)$ & $\mathrm{SS}_{\mathrm{D}(\mathrm{S})}$ & $\mathrm{MS}_{\mathrm{D}(\mathrm{S})}$ & $\sigma^{2}+\mathrm{k}_{1} \sigma_{\mathrm{D}}^{2}$ \\
Offspring (error) & $\mathrm{S} \times \mathrm{D} \times(\mathrm{n}-1)$ & $\mathrm{SS}$ & $\mathrm{MS}$ & $\sigma^{2}$ \\
Total & $\mathrm{N}-1$ & $\mathrm{SS}$ & & \\
\hline
\end{tabular}

The key elements in Table 1 were calculated as follows:

$$
\begin{aligned}
& S S_{S}=\sum_{i=1}^{S} \frac{x_{i . .}^{2}}{n_{i \cdot}}-\frac{x_{\ldots .}^{2}}{n_{. .}} \\
& S S_{D / S}=\sum_{i=1}^{S} \sum_{j=1}^{D_{i}} \frac{x_{i j \cdot}^{2}}{n_{i j}}-\sum_{i=1}^{S} \frac{x_{i \cdot}^{2}}{n_{i \cdot}} \\
& S S_{e}=\sum_{i=1}^{S} \sum_{j=1}^{D_{i}} \sum_{k=1}^{n_{i j}} x_{i j k}^{2}-\sum_{i=1}^{S} \sum_{j=1}^{D_{i}} \frac{x_{i j .}^{2}}{n_{i j}}
\end{aligned}
$$

Sires heritability was estimated as $\mathrm{h}_{\mathrm{F}}^{2}=4 \sigma_{\mathrm{F}}^{2} /\left(\sigma_{\mathrm{F}}^{2}+\sigma_{\mathrm{D}}^{2}+\sigma_{\mathrm{e}}^{2}\right)$, dams (dam) heritability was estimated as $\mathrm{h}_{\mathrm{D}}^{2}=4 \sigma_{\mathrm{D}}^{2} /\left(\sigma_{\mathrm{F}}^{2}+\sigma_{\mathrm{D}}^{2}+\sigma_{\mathrm{e}}^{2}\right)$, pooled (sire and dam) heritability was estimated as $\mathrm{h}_{\mathrm{F}+\mathrm{D}}^{2}=2\left(\sigma_{\mathrm{F}}^{2}+\sigma_{\mathrm{D}}^{2}\right) /\left(\sigma_{\mathrm{F}}^{2}+\sigma_{\mathrm{D}}^{2}+\sigma_{\mathrm{e}}^{2}\right)$.

The phenotypic variance $\left(\mathrm{V}_{\mathrm{P}}\right)$ was decomposed into the additive genetic variance $\left(\mathrm{V}_{\mathrm{A}}\right)$, non-additive genetic variance $\left(\mathrm{V}_{\mathrm{N}}\right)$ and environmental variance $\left(\mathrm{V}_{\mathrm{E}}\right)$, and the environmental variance $\left(\mathrm{V}_{\mathrm{E}}\right)$ was decomposed into the common environmental variance $\left(\mathrm{V}_{\mathrm{EC}}\right)$ and the specific environmental variance $\left(\mathrm{V}_{\mathrm{ES}}\right)$ using the standard decomposition of variance components (Falconer, 1989). The causal components of variance were estimated from the full- and half-sib covariance using the relationships in Table 2.

Table 2. Relationships between the covariance of full and half-sibs and causal components of phenotypic variance

\begin{tabular}{llll}
\hline $\begin{array}{c}\text { Component of } \\
\text { variance }\end{array}$ & \multicolumn{1}{c}{$\begin{array}{c}\text { Covariance } \\
\text { components }\end{array}$} & \multicolumn{1}{c}{ Causal components } & Calculation of component of variance \\
\hline$\sigma^{2}{ }_{\mathrm{S}}$ & $\mathrm{COV}_{\mathrm{HS}}$ & $1 / 4 \mathrm{~V}_{\mathrm{A}}$ & $\left\{\mathrm{MS}-\left[\left(\mathrm{MS}_{\mathrm{M}(\mathrm{S})}-\mathrm{MS}_{\mathrm{E}}\right) / \mathrm{k}_{1}\right] \times \mathrm{k}_{2}-\mathrm{MS}_{\mathrm{E}}\right\} / \mathrm{k}_{3}$ \\
$\sigma_{\mathrm{D}}^{2}$ & $\mathrm{COV}_{\mathrm{FS}}-\mathrm{COV}_{\mathrm{HS}}$ & $1 / 4 \mathrm{~V}_{\mathrm{A}}+1 / 4 \mathrm{~V}_{\mathrm{NA}}+\mathrm{V}_{\mathrm{EC}}$ & $\left(\mathrm{MS}_{\mathrm{D}(\mathrm{S})}-\mathrm{MS}_{\mathrm{E}}\right) / \mathrm{k}_{1}$ \\
$\sigma^{2}$ & $\mathrm{~V}_{\mathrm{P}}-\mathrm{COV}_{\mathrm{FS}}$ & $1 / 2 \mathrm{~V}_{\mathrm{A}}+3 / 4 \mathrm{~V}_{\mathrm{D}}+\mathrm{V}_{\mathrm{ES}}$ & $\mathrm{MS}_{\mathrm{E}}$ \\
$\sigma^{2}{ }_{\mathrm{T}}=\sigma_{\mathrm{S}}^{2}+\sigma_{\mathrm{D}}^{2}+\sigma^{2}$ & $\mathrm{~V}_{\mathrm{P}}$ & $\mathrm{V}_{\mathrm{A}}+\mathrm{V}_{\mathrm{NA}}+\mathrm{V}_{\mathrm{EC}}+\mathrm{V}_{\mathrm{ES}}$ & \\
$\sigma^{2}{ }_{\mathrm{S}}+\sigma_{\mathrm{D}}^{2}$ & $\mathrm{COV}$ & $1 / 2 \mathrm{~V}_{\mathrm{A}}+1 / 4 \mathrm{~V}_{\mathrm{D}}+\mathrm{V}_{\mathrm{EC}}$ & \\
\hline
\end{tabular}

Heritabilities were computed using the relationships: $h^{2}=\mathrm{V}_{\mathrm{A}} /\left[\mathrm{V}_{\mathrm{A}}+\mathrm{V}_{\mathrm{NA}}+\mathrm{V}_{\mathrm{E}}\right]$. Thus heritabilites in the narrow sense of paternal half-sib and maternal half-sib and full-sib were computed using the respective relationships: $h_{\mathrm{HS}(\mathrm{D})}=4 \times \sigma_{\mathrm{D}}{ }_{\mathrm{D}} /\left(\sigma_{\mathrm{S}}{ }_{\mathrm{S}}+\sigma_{\mathrm{D}}{ }_{\mathrm{D}}+\sigma^{2}\right)$.

The standard errors of heritabilities and genetic correlations were estimated as follows: 


$$
\sigma_{h_{S, M}^{2}}=2 \sqrt{\frac{2\left(1-r_{F S}\right)^{2}\left[1+\left(k_{1}-1\right) r_{F S}\right]^{2}}{k_{1}\left(k_{1}-1\right)(M-1)}}
$$

\section{Results}

The goal of the sampling procedure was to obtain 60 progeny for each of the 42 dams and averaged 148 progeny for each of the 17 sires and 2520 progeny for the sampling period.

\section{The Accumulation Growth of Body Weight and The Body Size at 3 and 5 Months}

The means, standard deviation and coefficients of variation (\%) for the accumulation growth of body weight and the characters of body size at 3 and 5 months were calculated in Table 3.

Table 3. Mean and Standard deviation of the accumulation growth

\begin{tabular}{ccccccccc}
\hline \multirow{2}{*}{ Month } & Trait & BW/g & TL/cm & BL/cm & FASD/cm TASD/cm FASW/cm PCL/cm \\
\hline \multirow{3}{*}{3} & Mean & 4.325 & 8.890 & 7.537 & 0.961 & 0.989 & 0.900 & 2.100 \\
& $\begin{array}{c}\text { Standard } \\
\text { deviation }\end{array}$ & 0.394 & 0.620 & 0.550 & 0.084 & 0.083 & 0.075 & 0.152 \\
& CV $(\%)$ & $10.98 \%$ & $14.34 \%$ & $13.70 \%$ & $11.44 \%$ & $11.92 \%$ & $12.00 \%$ & $13.82 \%$ \\
\hline \multirow{2}{*}{5} & $\begin{array}{c}\text { Mean } \\
\text { Standard }\end{array}$ & 14.95 & 12.11 & 10.36 & 1.48 & 1.48 & 1.32 & 2.93 \\
& $\begin{array}{c}\text { deviation } \\
\text { CV (\%) }\end{array}$ & 18.73 & 0.79 & 0.70 & 0.11 & 0.12 & 0.10 & 0.21 \\
& CV $(10 \%$ & $6.52 \%$ & $6.76 \%$ & $7.43 \%$ & $8.11 \%$ & $7.58 \%$ & $7.17 \%$ \\
\hline
\end{tabular}

The coefficients of variations varied considerably among the various traits. The rank order of the variations was body weight $(10.98 \%)$ that were higher; the body size (ranged from $11.44 \%$ to $14.34 \%$ ) that were slightly lower at 3 month. The rank order of the variations was body weight $(18.26 \%)$ that were higher; the body size (ranged from $6.52 \%$ to $8.11 \%$ ) that were lower at 5 month.

\section{Analysis of Variance of Body Weight and Body Size}

Analysis of variance demonstrated great differences in wet weight and diameter of juveniles from different females mated with the same male and between males at both 3 and 5 months of age (Table 4).

Effective mean number of offspring for sires and dams was computed as follows:

Effective mean number of offspring in dams within sires: $\mathrm{K}_{1}=\left[\mathrm{N}-\Sigma\left(\mathrm{n}_{\mathrm{ij}}{ }^{2} / \mathrm{dn} \mathrm{n}_{\mathrm{i}}\right)\right] /(\mathrm{D}-\mathrm{S})=$ 60

Effective mean number of offspring in dams: $\mathrm{K}_{2}=\left[\Sigma\left(\mathrm{n}_{\mathrm{ij}}{ }^{2} / \mathrm{dn}_{\mathrm{i}}\right)-\Sigma\left(\mathrm{n}_{\mathrm{ij}}{ }^{2} / \mathrm{N}\right)\right] /(\mathrm{S}-1)=60$

Effective mean number of offspring in sires: $\mathrm{K}_{3}=\left(\mathrm{N}-\Sigma \mathrm{dn}_{\mathrm{i}}^{2} / \mathrm{N}\right) /(\mathrm{S}-1)=148$ 
Table 4. Analysis of variance for components of phenotypic variation of Litopenaeus vannamei at 3 and 5 months of age.

\begin{tabular}{|c|c|c|c|c|c|c|}
\hline & \multicolumn{3}{|c|}{ Body weight (BW) } & \multicolumn{3}{|c|}{ Total length (TL) } \\
\hline $\begin{array}{l}\text { Source of } \\
\text { variance }\end{array}$ & $\begin{array}{l}\text { Degrees of } \\
\text { freedom }(\mathrm{df})\end{array}$ & $\begin{array}{c}\text { Mean square } \\
\text { (MS) }\end{array}$ & F-value & $\begin{array}{c}\text { Mean } \\
\text { square } \\
(\mathrm{MS})\end{array}$ & F-value & $\begin{array}{l}\text { Expected mean } \\
\text { square E (MS) }\end{array}$ \\
\hline 3 months & & & & & & \\
\hline Dam & 41 & 1071.26 & $14.27 * *$ & 9.08 & $9.87 * *$ & \\
\hline Sire & 16 & 2048.56 & $27.29 * *$ & 17.21 & $18.71 * *$ & $\sigma^{2}+k_{2} \sigma_{D}^{2}+k_{3} \sigma_{S}^{2}$ \\
\hline Dams/sires & 25 & 719.43 & $9.58 * *$ & 6.89 & $7.49 * *$ & $\sigma^{2}+\mathrm{k}_{1} \sigma_{\mathrm{D}}^{2}$ \\
\hline Full-sibs/dams & 2478 & 75.07 & & 0.92 & & $\sigma^{2}$ \\
\hline $\begin{array}{l}\text { Total } \\
5 \text { months }\end{array}$ & 2519 & & & & & \\
\hline Dams & 41 & 9438 & $19.14 * *$ & 80.53 & $15.85 * *$ & \\
\hline Sire & 16 & 18759 & $38.05 * *$ & 151.33 & $29.79 * *$ & ${ }^{2}+k_{2} \sigma_{D}^{2}+k_{3} \sigma_{S}^{2}$ \\
\hline Dams/sires & 25 & 5625 & $11.41 * *$ & 61.56 & $12.12 * *$ & $\sigma^{2}+\mathrm{k}_{1} \sigma_{\mathrm{D}}^{2}$ \\
\hline Full-sibs/dams & 2478 & 493 & & 5.08 & & $\sigma^{2}$ \\
\hline Total & 2519 & & & & & \\
\hline
\end{tabular}

Table 4. Analysis of variance for components of phenotypic variation of Litopenaeus vannamei at 3 and 5 months of age (Continue 1).

\begin{tabular}{|c|c|c|c|c|c|c|}
\hline & \multicolumn{3}{|c|}{ Body length (BL) } & \multicolumn{3}{|c|}{ First abdominal segment depth (FASD) } \\
\hline $\begin{array}{l}\text { Source of } \\
\text { variance }\end{array}$ & $\begin{array}{l}\text { Degrees of } \\
\text { freedom }(\mathrm{df})\end{array}$ & $\begin{array}{c}\text { Mean square } \\
\text { (MS) }\end{array}$ & F-value & $\begin{array}{c}\text { Mean } \\
\text { square } \\
(\mathrm{MS})\end{array}$ & F-value & $\begin{array}{l}\text { Expected mean } \\
\text { square E (MS) }\end{array}$ \\
\hline 3 months & & & & & & \\
\hline Dam & 41 & 4083 & $5.62 * *$ & 6.01 & $6.75 * *$ & \\
\hline Sire & 16 & 7266 & $9.99 * *$ & 10.71 & $12.03 * *$ & ${ }^{2}+\mathrm{k}_{2} \sigma_{\mathrm{D}}^{2}+\mathrm{k}_{3} \sigma_{\mathrm{S}}^{2}$ \\
\hline Dams/sires & 25 & 5567 & $7.66^{* *}$ & 6.97 & $7.83 * *$ & $\sigma^{2}+k_{1} \sigma_{D}^{2}$ \\
\hline Full-sibs/dams & 2478 & 727 & & 0.89 & & $\sigma^{2}$ \\
\hline $\begin{array}{l}\text { Total } \\
5 \text { months }\end{array}$ & 2519 & & & & & \\
\hline Dams & 41 & 7997 & $7.58 * *$ & 69.16 & $8.57 * *$ & \\
\hline Sire & 16 & 13172 & $12.48 * *$ & 108.29 & $13.42 * *$ & ${ }^{2}+\mathrm{k}_{2} \sigma_{\mathrm{M}}^{2}+\mathrm{k}_{3} \sigma_{\mathrm{S}}^{2}$ \\
\hline Dams/sires & 25 & 5343 & $5.06 * *$ & 65.16 & $8.06^{* *}$ & $\sigma^{2}+\mathrm{k}_{1} \sigma_{\mathrm{D}}^{2}$ \\
\hline Full-sibs/dams & 2478 & 635 & & 8.07 & & $\sigma^{2}$ \\
\hline Total & 2519 & & & & & \\
\hline
\end{tabular}


Table 4. Analysis of variance for components of phenotypic variation of Litopenaeus vannamei at 3 and 5 months of age (Continue 2).

\begin{tabular}{|c|c|c|c|c|c|c|}
\hline & \multicolumn{3}{|c|}{ Third abdominal segment depth (TASD) } & \multicolumn{3}{|c|}{ First abdominal segment width (FASW) } \\
\hline $\begin{array}{l}\text { Source of } \\
\text { variance }\end{array}$ & $\begin{array}{l}\text { Degrees of } \\
\text { freedom }(\mathrm{df})\end{array}$ & $\begin{array}{c}\text { Mean square } \\
\text { (MS) }\end{array}$ & F-value & $\begin{array}{c}\text { Mean } \\
\text { square } \\
(\mathrm{MS})\end{array}$ & F-value & $\begin{array}{l}\text { Expected mean } \\
\text { square E (MS) }\end{array}$ \\
\hline \multicolumn{7}{|l|}{3 months } \\
\hline Dam & 41 & 1168.64 & $13.14 * *$ & 18.88 & $9.91 * *$ & \multirow{3}{*}{$\begin{array}{c}\sigma^{2}+\mathrm{k}_{2} \sigma_{\mathrm{D}}^{2}+\mathrm{k}_{3} \sigma_{\mathrm{S}}^{2} \\
{ }^{2}+\mathrm{k}_{1} \sigma\end{array}$} \\
\hline Sire & 16 & 2145.37 & $24.13 * *$ & 25.42 & $18.79 * *$ & \\
\hline Dams/sires & 25 & 766.43 & $8.62 * *$ & 16.09 & $6.21 * *$ & \\
\hline Full-sibs/dams & 2478 & 88.92 & & 1.86 & & $\sigma^{2}$ \\
\hline \multicolumn{7}{|l|}{5 months } \\
\hline Dams & 41 & 926.02 & $36.51 * *$ & 183.26 & $25.28 * *$ & \multirow{5}{*}{$\begin{array}{c}{ }^{2}+\mathrm{k}_{2} \sigma_{\mathrm{D}}^{2}+\mathrm{k}_{3} \sigma_{\mathrm{S}} \\
{ }^{2} \\
\sigma^{2}+\mathrm{k}_{1} \sigma^{\mathrm{D}} \mathrm{D} \\
\sigma^{2}\end{array}$} \\
\hline Sire & 16 & 563.48 & $22.22 * *$ & 156.38 & $21.57 * *$ & \\
\hline Dams/sires & 25 & 220.52 & $8.62 * *$ & 63.62 & $8.78 * *$ & \\
\hline Full-sibs/dams & 2478 & 25.36 & & 7.25 & & \\
\hline Total & 2519 & & & & & \\
\hline
\end{tabular}

Table 4. Analysis of variance for components of phenotypic variation of Litopenaeus vannamei at 3 and 5 months of age (Continue 3).

\begin{tabular}{|c|c|c|c|c|}
\hline \multirow[b]{2}{*}{ Source of variance } & \multicolumn{4}{|c|}{ Partial carapace length (PCL) } \\
\hline & $\begin{array}{l}\text { Degrees of } \\
\text { freedom }(\mathrm{df})\end{array}$ & Mean square (MS) & F-value & $\begin{array}{c}\text { Expected mean } \\
\text { square E (MS) }\end{array}$ \\
\hline \multicolumn{5}{|l|}{3 months } \\
\hline Dam & 41 & 1529.64 & $18.37 * *$ & \multirow{4}{*}{$\begin{array}{c}\sigma^{2}+\mathrm{k}_{2} \sigma_{\mathrm{D}}+\mathrm{k}_{3} \sigma_{\mathrm{S}}^{2} \\
\sigma^{2}+\mathrm{k}_{1} \sigma^{\mathrm{D}} \mathrm{D} \\
\sigma^{2}\end{array}$} \\
\hline Sire & 16 & 2145.28 & $25.76 * *$ & \\
\hline Dams/sires & 25 & 738.25 & \multirow[t]{2}{*}{$8.86 * *$} & \\
\hline Full-sibs/dams & 2478 & 83.54 & & \\
\hline Total & 2519 & & & \\
\hline \multicolumn{5}{|l|}{5 months } \\
\hline Dams & 41 & 2345.88 & $24.36 * *$ & \multirow{5}{*}{$\begin{array}{c}2{ }^{2}+\mathrm{k}_{2} \sigma_{\mathrm{D}}+\mathrm{k}_{3} \sigma_{\mathrm{S}} \\
{ }^{2}{ }^{2}+\mathrm{k}_{1} \sigma^{\mathrm{D}} \\
{ }_{2}\end{array}$} \\
\hline Sire & 16 & 2567.16 & $26.66 * *$ & \\
\hline Dams/sires & 25 & 841.22 & \multirow[t]{3}{*}{$8.74 * *$} & \\
\hline Full-sibs/dams & 2478 & 96.29 & & \\
\hline Total & 2519 & & & \\
\hline
\end{tabular}

\section{Estimations of Heritability and Test of Significance}

Heritabilities were calculated on the result of component of variance and covariance and test of significance $\left(\mathrm{t}=\mathrm{h}^{2} / \sigma_{h}{ }^{2}\right)$ of heritability were shown as Table 5 .

All of the heritabilities were significantly different from zero (t-test, $\mathrm{p}<0.01$ ). 
Table 5. Heritabilities (h2) and their standard error ( $\sigma \mathrm{h} 2)$

\begin{tabular}{|c|c|c|c|c|c|c|c|c|}
\hline Month & Trait & $\mathrm{BW} / \mathrm{g}$ & $\mathrm{TL} / \mathrm{cm}$ & $\mathrm{BL} / \mathrm{cm}$ & $\begin{array}{c}\text { FASD/ } \\
\mathrm{cm}\end{array}$ & $\begin{array}{c}\text { TASD/ } \\
\mathrm{cm}\end{array}$ & $\begin{array}{l}\text { FASW } \\
/ \mathrm{cm}\end{array}$ & $\begin{array}{c}\text { PCL/c } \\
\mathrm{m}\end{array}$ \\
\hline \multirow{4}{*}{3} & Heritability $\left(h^{2}\right)$ & $0.452 * *$ & $0.368 * *$ & $\begin{array}{c}0.387 * \\
*\end{array}$ & $\begin{array}{c}0.403 * \\
*\end{array}$ & $\begin{array}{c}0.415^{*} \\
*\end{array}$ & $\begin{array}{c}0.441 * \\
*\end{array}$ & $0.422 * *$ \\
\hline & $\begin{array}{l}\text { Standard errors of heritability } \\
\qquad\left(\sigma_{h}^{2}\right)\end{array}$ & 0.029 & 0.026 & 0.0258 & 0.027 & 0.031 & 0.026 & 0.032 \\
\hline & $\begin{array}{c}\text { Test of significance } \\
\text { (t-test) }\end{array}$ & 15.586 & 14.154 & 15.000 & 14.926 & 13.387 & 16.962 & 13.188 \\
\hline & Heritability $\left(h^{2}\right)$ & $0.515^{* *}$ & $0.394^{* *}$ & $\begin{array}{c}0.409 * \\
*\end{array}$ & $\begin{array}{c}0.412 * \\
*\end{array}$ & $\begin{array}{c}0.420 * \\
*\end{array}$ & $\begin{array}{c}0.429 * \\
*\end{array}$ & $0.415^{* *}$ \\
\hline \multirow[t]{2}{*}{5} & $\begin{array}{l}\text { Standard errors of heritability } \\
\qquad\left(\sigma_{h}^{2}\right)\end{array}$ & 0.031 & 0.028 & 0.028 & 0.028 & 0.029 & 0.029 & 0.028 \\
\hline & $\begin{array}{c}\text { Test of significance } \\
\text { (t-test) }\end{array}$ & 16.595 & 14.161 & 14.476 & 14.538 & 14.703 & 14.888 & 14.600 \\
\hline
\end{tabular}

Notes: $\mathrm{t} 0.05=1.960, \mathrm{t} 0.01=2.576$. The symbol $* *$ denotes very significant.

\section{Discussion}

An animal model that includes a random effect for the additive genetic effect of each individual and incorporates a complete set of additive genetic relationships among all the individuals, allows an unbiased estimations of variance components, even for the data involving selection and non-random mating (Maluwa and Gjerde, 2006; Gao et al, 2008). In the present investigation full-sib family was taken as a random effect in an animal model to account for the covariance among full-sibs caused by common environmental, maternal and non-additive genetic effects, as well as half-sib family to account for covariance among half-sibs caused by common environmental, maternal, paternal and non-additive genetic effects. The results from the analyses indicated that this model was expected to be unbiased estimates of genetic parameters for the base population.

The estimated heritabilities indicate significant additive genetic variation for body weight and the characters of body size at 3 and 5 months. Sire heritabilties for the different variables were lower than dam heritabilities in many cases, however, all of the heritabilities were significant different from zero ( $t$-test, $\mathrm{p}<0.01$ ). These results show that it is possible to increase the body weight when selection is applied.

Although dam effects are omnipresent in the study, they were strongly reduced from the data of S. intermedius reported by Liu et al. (2005). However, the fact that they are still present after the juvenile phase may indicate that the quality of yolk reserves plays a role in early development. Dam effects may persist after the onset of exogenous feeding. Crandell and Gall (1993) reported that dam effects persist up to 2 years in rainbow trout and up to 18-month-old Arctic char (Nilsson, 1994).

\section{Acknowledgments}

This work was supported by the Agricultural Science and Technology Achievement Transformation Fund Project of Ministry of Science and Technology, China (No.2012GB2E200361), the Key laboratory of Marine Biology, Institute of Oceanology, Chinese Academy of Sciences and the Northwest A\&F University experimental demonstration station (base) and innovation of science and technology achievement transformation project (No. XNY2013-4).Comments from anonymous reviewers have greatly improved the manuscript. 


\section{References}

[1] Andriantahina, F., Xiaolin, L., Huang, H., Jianhai, X., Yang, C., 2011. Comparison of reproductive performance and offspring quality of domesticated Pacific white shrimp, Litopenaeus vannamei. Aquaculture 324-325, 194-200.

[2] Nguyen Hong Nguyen*, Jane Quinn1, Daniel Powell, Abigail Elizur, Ngo Phu Thoa, Josephine Nocillado, Robert Lamont, Courtney Remilton and Wayne Knib. Heritability for body colour and its genetic association with morphometric traits in Banana shrimp (Fenneropenaeus merguiensis). BMC Genetics 2014, 15:132-142.

[3] Kenway M, Macbeth M, Salmon M, McPhee C, Benzie J, Wilson K, Knibb W: Heritability and genetic correlations of growth and survival in black tiger prawn Penaeus monodon reared in tanks. Aquaculture 2006, 259(1-4):138-145.

[4] Whatmore P, Nguyen NH, Miller A, Lamont R, Powell D, D’Antignana T, Bubner E, Elizur A, Knibb W: Genetic parameters for economically important traits in yellowtail kingfish Seriola lalandi. Aquaculture 2013, 400:77-84.

[5] Hung D, Nguyen NH, Ponzoni RW, Hurwood DA, Mather PB: Quantitative genetic parameter estimates for body and carcass traits in a cultured stock of giant freshwater prawn (Macrobrachium rosenbergii) selected for harvest weight in Vietnam. Aquaculture 2013, 404-405:122-129.

[6] Arcos, F.G., Racotta, I.S., Ibarra, A.M., 2004. Genetic parameter estimates for reproductive traits and egg composition in Pacific white shrimp Penaeus (Litopenaeus) vannamei. Aquaculture 236, 151-165.

[7] Arcos, F.G., Racotta, I.S., Palacios, E., Ibarra, A.M., 2005. Ovary development at the onset of gametogenesis is genetically determined and correlated with reproductive traits at maturity in shrimp Litopenaeus (Penaeus) vannamei. Marine Biology 148, $339-446$.

[8] Argue, B.J., Arce, S.M., Lotz, J.M., Moss, S.M., 2002. Selective breeding of Pacific white shrimp (Litopenaeus vannamei) for growth and resistance to Taura Syndrome Virus. Aquaculture 204, 447-460.

[9] Benzie, J.A.H., Kenway, M., Trott, L., 1997. Estimates for the heritability of size in juvenile Penaeus monodon prawns from half-sib mating. Aquaculture 152, 49-53.

[10] Charo-Karisa, H., Komen, H., Rezk, M.A., Ponzoni, R.W., van Arendonk, J.A.M., Bovenhuis, H., 2006. Heritability estimates and response to selection for growth of Nile tilapia (Oreochromis niloticus) in low-input earthen pond. Aquaculture 261, 479-486.

[11] Coman, G.J., Arnold, S.J., Wood, A.T., Kube, P.D., 2010. Age: Age genetic correlations for weight of Penaeus monodon reared in broodstock tank systems. Aquaculture 307, 1-5.

[12] Comstock, R.E., Robinson, H.F., 1952. Estimation of average dominance of genes. In: Gowen, J. W. (Ed.), Heterosis. Iowa State College Press, Ames.

[13] Eknath, A.E, Bentsen, H.B, Ponzoni, R.W., Rye, M., Nguyen, N.H., Thodesen, J., Gjerd, B., 2007. Genetic improvement of farmed tilapias: Composition and genetic parameters of a synthetic base population of Oreochromis niloticus for selective breeding. Aquaculture 273, 1-14. 
[14] Fishback, G.A., Danzmann, R.G., Ferguson, M.M., Gibson, J.P., 2002. Estimates of genetic parameters and genotype by environment interactions for growth traits of rainbow trout (Oncorhynchus mykiss) as inferred using molecular pedigrees. Aquaculture 206, 137-150.

[15] Gall, A.E.G., Neira, R., 2004. Genetic analysis of female reproduction traits of farmed coho salmon (Oncorhyncus kisutch). Aquaculture 234, 143-154.

[16] Gall, G.A.E., Bakar, Y., 1999. Stocking desity and tank size in the design of breeding improvement programs for body size of tilapia. Aquaculture 173, 197-205.

[17] Gall, G.A.E., Gross, S.J., 1978. A genetics analysis of the performance of three rainbow trout broodstocks. Aquaculture 15, 113-127.

[18] Gao, B.Q., Liu, P., Li, J., Dai, F.Y., Luo, Y., Dai, Y.J., 2008. Heterosis of F1 Portunus trituberculatus from mating and crosses among the different geographical populations. Oceanol. Limnol. Sin. 39, 291-296.

[19] Gitterle, T., Rye, M., Salte, R., Cock, J., Johansen, H., Lozano, C., Suarez, J.A., Gjerde, B., 2005. Genetic (co)variation in harvest body weight and survival in Penaeus (Litopenaeus) vannamei under standard commercial conditions. Aquaculture 243, 83-92.

[20] Gjedrem, T., Olesen, I., 2005. Basic statistical parameters. In: Gjedrem, T. (Ed.), Selection and Breeding Programs in Aquaculture. Springer, Dordrecht, The Netherlands, pp. 45-72.

[21] Henderson, C.R., 1973. Sire evaluation and genetic trend. Proc. Animal Breeding and Genetics Symposium in Honor of Dr. J.L. Lush, Blacksburg, VA, August 1973. American Society of Animal Science, Champaign, IL, 10-41.

[22] Hetzel, D.J.S., Crocos, P.J., Davis, G.P., Moore, S.S., Preston, N.C., 2000. Response to selection and heritability for growth in the Kuruma prawn, Penaeus japonicus. Aquaculture 181, 215-223.

[23] Hilbish, T.J., Winn, E.P., Rawson, P.D., 1993. Genetic variation and covariation during larval and juvenile growth in Mercenaria mercenaria. Marine biology 115, 97-104.

[24] Huang, N., Gall, G.A.E., 1990. Correlation of body weight and reproductive characteristics in rainbow trout. Aquaculture 86, 191-200.

[25] Ibarra, A.M., Arcos, F.G., Famula, T.R., Palacious, E., Racotta, I.S., 2005. Heritability of the categorical trait 'number of spawns' in Pacific white shrimp Penaeus (Litopenaeus) vannamei. Aquaculture 250, 95-101.

[26] Ibarra, A.M., Ramirez, J.L., Ruiz, C.A., Cruz, P., Avila, S., 1999. Realized heritabilities and genetic correlation after dual selection for total weight and shell width in catarina scallop (Argopecten ventricosus). Aquaculture 175, 227-241.

[27]Jonasson, J., 1993. Selection experiments in salmon ranching. I. Genetic and environmental sources of variation in survival and growth in freshwater. Aquaculture $109,225-236$. 
[28] Jonasson, J., Stefansson, S.E., Gudnason, A., Steinarsson, A., 1999. Genetic variation for survival and shell length of cultured red abalone (Haliotis rufescens) in Iceland. Journal of Shellfish Research 18, 621-625.

[29] Kenway, M., Macbeth, M., Benzie, J., Knibb, W., Wilson, K., 2006. Heritability and genetic correlations of growth and survival in black tiger prawn Penaeus monodon reared in tanks. Aquaculture 259, 138-145.

[30] Kovac, M., Groeneveld, E., 2003. VCE5 user's guide and manual version 5.1. Department of Animal Sciences, University of Ljubljana, Ljubljana, 68 pp.

[31] Macbeth, M., Kenway, M., Salmon, M., Benzie, J., Knibb, W., Wilson, K., 2007. Heritability of reproductive traits and genetic correlations with growth in the black tiger prawn Penaeus monodon reared in tanks. Aquaculture 270, 51-56.

[32] Maluwa, A.O., Gjerde, B., 2006. Estimation of the additive and non additive genetic components for harvest body weight in the F2 generation of Oreochromis shiranus. Aquaculture 259, 38-46.

[33] Maluwa, A.O., Gjerde, B., 2007. Response to selection for harvest body weight of Oreochromis shiranus. Aquaculture 273, 33-41.

[34] Neira, R., Díaz, N.F., Gall, G.A.E, Gallardo, J.A., Lhorente, J.P., Manterola, R., 2006. Genetic improvement in Coho salmon (Oncorhynchus kisutch). I: Selection response and inbreeding depression on harvest weight. Aquaculture 257, 9-17.

[35] Nhan, D.T., Wille, M., Le Hung, L.T., Sorgeloos, P., 2009. Comparison of reproductive performance and offspring quality of giant freshwater prawn (Macrobrachium rosenbergii) broodstock from different regions. Aquaculture 298, 36-42.

[36] Norris, A.T., Cunningham, E.P., 2004. Estimates of phenotypic and genetic parameters for flesh colour traits in farmed Atlantic salmon based on multiple trait animal model. Livest. Prod. Sci. 89, 209-222.

[37] Perez-Rostro, C.I., Ibarra, A.M., 2003. Quantitative genetic parameter estimates for size and growth rate traits in Pacific white shrimp, Penaeus vannamei (Boone 1931) when reared indoors. Aquac. Res. 34, 543-553.

[38] Rezk, M.A., Ponzoni, R.W., Khaw, H.L., Kamel, E., Dawood, T., John, G., 2009. Selective breeding for increased body weight in a synthetic breed of Egyptian Nile tilapia, Oreochromis niloticus: Response to selection and genetic parameters. Aquaculture 293, 187-194.

[39] Su, Guo-Sheng, Liljedahl, L.E., Gall, G.A.E., 1997. Genetic and environmental variation of female reproductive traits in rainbow trout (Oncorhynchus mykiss). Aquaculture 154, 113-122.

[40] Toro, J.E., 1990. Response to selection, heritability and genetic correlation for live weight and shell height in the European oyster Ostrea edulis Linne. Rev. Biol. Mar. 25, 135-146.

[41] Xiao-lin Liua, Ya-qing Chang, Jian-hai Xiang*, Xue-bin Cao. Estimates of genetic parameters for growth traits of the sea urchin,Strongylocentrotus intermedius. Aquaculture 243 (2005) 27-32. 
[42] Crandell, P.A., Gall, G.A.E.. The effects of sex on heritability estimates of body weight from data on individually tagged rainbow trout (Oncorhynchus mykiss). Aquaculture, 1993, 33, 89-96.

[43] Nilsson, J. Genetics of growth of juvenile Arctic char. Trans. Am. Fish. Soc.1994, $123,430-434$. 